\title{
India's Foreign Policy in Indo-Pacific Region and Its Impact for Southeast Asia's Regional Interest
}

\author{
Mansur Juned \\ Universitas Pembangunan Nasional Veteran Jakarta
}

Doi: 10.36941/ajis-2019-0029

\begin{abstract}
This study focusing on international relations field, seeks to explore the rise of India as one of the major world powers that actively and subtlely distributes its geostrategic power and its influence on the regional interests of Southeast Asia. The form of implementation of India's national interests related to efforts to become a new rising global power country is to pay attention to the security sector which is more accommodating to peace and the economic sector which tends to be more cooperative. By using qualitative method in form of offensive realism theory in explaining India's strategy in realizing look east policy in an effort to achieve its national interests, as well as leading to an 'expansionist' in fighting for strategic resources, there are two basic strategies that can be implemented by a country, namely balancing and buck-passing. Balancing is carried out by including in the form of supervision which will appear through internal balancing and external balancing. The form of implementation of internal balancing is done by strengthening the military and improving the economy. While external balancing is done by aggressiveness that is external in nature outside the national boundary, namely cooperation and forming the process of regional integration, buck-passing is the main alternative to balancing, the state avoids the occurrence of war by making other countries a shield. The form of implementation of India's balancing strategy is by means of aggressiveness, because great power is directly involved in threatening the opposing country which is an opposition state in the international political system. This Indian strategy makes Southeast Asian countries a potential region to become a strategic partner in the field of economy and defense, making ASEAN as a whole an effective buffer zone of various great power interests.
\end{abstract}

Keywords: India, foreign policy, maritime, Asia Pacific, ASEAN

\section{Introduction}

India as a country that has the potential to be great power will tend to use an offensive strategy. Therefore, India chose a balancing strategy to deal with various countries that could threaten its national interests. On the contrary, in regions that are regionally integrated, India chooses a buckpassing strategy, which is to make some countries as proxies for its national interests. Mearsheimer (2001) explained that balancing strategies can be carried out by increasing the economic capacity and followed by an increase in the defense budget and military deployment to an area. Rapid economic growth made India began to be oriented towards increasing the capacity of the maritime industry, both for trade and defense activities. This is an important policy carried out by India in addition to trying to establish cooperation with countries around the Indian Ocean Region as explicitly stated in the Sagarmala or SAGAR (Security and Growth for All in the Region) docs introduced by Modi in 2015 (Chaturvedy, 2017).

Alfred T. Mahan (2013) in a book entitled "The Influence of Sea Power upon History 16601753 mentions the importance of the role of the sea as an aspect of the strength of a nation. The rise of India as an established economy, made India begin to look at other aspects in fulfilling its 
national interests. It can be said that India also adopted the Mahan's (2013) concept regarding the influence of sea power in its efforts to focus on geopolitical, diplomatic and military uses, followed by the construction of various ports. This Indian behavior is logical, according to Mahan's (2013) statement that "whoever controls the Indian Ocean dominates Asia ... in the 21st century, the destiny of the world will be decided on these waters". According to Mahan (2013), the strategic value of seas, especially for the placement of naval bases, can be analyzed from 3 things, namely; location, strengths and resources. In the form of implementation, India began to build several ports in the Indian Ocean waters in collaboration with Indonesia.

With ports built by and outside India, they can certainly be a gateway in their alleged market access for the fulfillment of India's national interests. Another reason is the desire of India as a commanding leader of the sea to spread the political and economic influences of India in the Indian Ocean region where the region is an important platform for India's national interests (Ladwig III, 2009; Brewster, 2010). With the establishment of various trade ports in various regions around the Indian Ocean, it has been proven that India has raised its dominance in the water domain to conduct power projection into the region in a structured manner based on objectives in national interest, at least as a balancing strategy against China (Pant, 2009; Berlin, 2006).

\section{Indian Interest in Maritime Domain}

"Whoever controls the Indian Ocean dominates Asia. This ocean is the key to the seven seas in the twenty-first century, the destiny of the world will be decided in these waters."

This excerpt was taken from a Navy Admiral who was an expert in geostrategic strategies, namely Alfred T. Mahan (2013). It was widely quoted in the literature related to the importance of aspects of the sea that can be influential in politics, economics, and security. The main principle of Mahan (2013) is that trust in the sea is an important pathway and is a source of natural resources for many countries because many things can be obtained. More deeply, it is very important for a country to have a tendency to control the sea to expand its strength and wealth, by exploiting trade capacity and trade routes. For Mahan (2013), another important thing is Sea Lines of Communication (SLOCs), namely, the path that includes the supply of SLOC resources which is important in today's global world, because the SLOC still faces many threats such as piracy and competition.

This 21st century is known as the century of the rise of Asia (Sachs, 2004). With the emergence of India as a world power, Asia's emerging powers is rapidly expanding economic development, thereby impacting on the need for energy and raw material supplies as well as market access related to accommodation of manufactured commodities, and export activities (Hopewell, 2015). Over the past few decades, Indian trade has grown rapidly. Indian exports were reported at 32.5 USD in 2019-Q3. This record rose compared to the previous record of 26.7 USD bn for 2019-Q2 (https://www.ceicdata.com/id/indicator/india/ total-exports).

Interestingly, more than $60 \%$ of the trade occurs in waterways, including the Indian Ocean, including in the South China Sea region. In 2018, Indonesia, ASEAN and India have shared vision of maritime cooperation by emphasizing efforts to strengthen investment and trade, to maintain the sustainability of marine resources, and to enhance maritime security. This initiative draws integrity relations from the Indian Ocean, through the South China Sea to South Pacific Ocean which aims to integrate water cooperation which includes aspects of the economy, welfare, and security. As one of the countries with the largest trading activities in the world, India is responsible for about more than $3 \%$ of global trade. Most Indian trade commodities are transported by ship, and this has an impact on India's economic interests, related to the main destination and starting point of international shipping lines. India is the largest shipowning country with the top 10 in the world, supported by Indian ambitions in the international scale maritime domain aimed at developing ports in Southeast Asia, around the Indian Ocean, and the Eastern Mediterranean region (Cordner, 2010; Brewster, 2010; Sakhuja, 2011). Large investments in the construction of port facilities in various locations have been planned and some are already underway.

Some important components of marine economic interests include energy security (oil and 
gas resources), preservation of fisheries, fishing are, freshwater resources, development of port facilities for logistic purposes, piracy and illegal control, security of trade routes, tourism development and ecosystem protection. In an effort to achieve these interests, India has expanded maritime cooperation to deal with various security threats both traditionally and non-traditionally, such as climate change, piracy and illegal trade that have cross-border implications.

India has expanded maritime cooperation in the sea with a number of countries in the Indian Ocean. The Indian-Sri Lanka Coastal and Aquatic Marine Center, Indian-Pakistani Waters Marine Center, Indian-Bangladesh Sea Waters Center-Myanmar are some examples of how India strengthens maritime cooperation. India continues to strive to improve its existence and its footprint in the Indian Ocean by carrying out various port infrastructure projects, managing and operating ports, gaining port access that has a tendency as a naval platform, obtaining military bases and conducting exercises with countries in the Indian Ocean region.

India has a tendency to be highly dependent on the Indian Ocean region to meet energy needs and also to run most economic and trade activities. However, India experiences 'Malacca Dilemma' because more than $80 \%$ of the oil resources and $30 \%$ of its natural gas are imported through the Malacca Strait. Hence, the importance of the Indian Ocean in Indian strategy can be calculated to dominate Indian maritime thinking.

\section{India's Interest in Asia Pacific and Its Impact on Southeast Asia}

The Indian Ocean has an important role in the development of the Indian economy, not only as an import route but also as an export basis. Therefore, India has a great interest in securing its trade routes along the Indian Ocean in the process of overcoming geographical barriers by establishing and operating several ports in the Indian Ocean.

India has invested in a number of port projects in strategic locations along the Indian Ocean region. Activities related to India's interests henceforth are to secure energy flows, in which a forecast showed that India's energy needs are expected to increase exponentially in the coming decades by estimating needs for energy sources also doubled for consumption in the next three decades. The movement of Indian oil imports shows that India heavily relies on several countries to supply its oil \& gas consumption needs. India's dependence on imports for energy needs is unlikely to decrease, given India's economic activity that continues to develop, thereby requiring the same pattern of trade movements to continue to increase for some time to come.

India has made investments in developing ports in these countries which are also based on various facts including economic, political, diplomatic and strategic reasons. This effort is a way for India to maintain its existence in the Indian Ocean region. Given that the port manager is an Indian company, Indian ships will eventually get a lot of profits to increase India's international trade in the long term.

In addition to establishing ports, India has taken a number of steps actively to establish its authority in the Indian Ocean and expand its naval capabilities. From the Indian point of view, the Indian naval fleet will only look for securing 'supplies' in the relevant ports, including those related to economic activity and anti-piracy operations in the Indian Ocean countries such as in Djibouti, Oman and Yemen.

The sea route in the movement of Indian oil activity for transportation through the Indian Ocean crosses the Strait of Hormuz, the Strait of Malacca and the Lombok Strait which is a critical point in geographic and geostrategic point of views. In addition, based on the Sea Lanes of Communication (SLOC), either through the Indian Ocean or the Pacific Ocean, India's position is in the naval shortage needed to prevent threats. India naturally needs a military strategy. The Indian maritime strategist mentioned the Malacca Strait is an important communication in the Indian Ocean and the Pacific Ocean Sea Lanes.

As a result, SLOC and energy flows were conducted through thinking about Indian maritime mastery of strategies. In theory, India is responsible for the opposition state which is being sidelined and will cause the possibility of conflict. In this regard, in international waters, the focus of the China's PLA Navy (PLAN) from offshore waters becomes a defense for offshore waters with the protection of the high seas. 
India continues to conduct naval operations throughout the world by preparing naval facilities in places that tend to have conditions squeezed by problems, while also ensuring economic stability accompanied by China's presence to strengthen its geostrategic power in the Indian Ocean, in collaboration with India's neighbours. Countries in the Indian Ocean region will be used to expand the reach of the People's Liberation Army Navy (PLAN) (Aneez \& Srilal, 2014). Along with the formation of the Maritime Silk Road (MSR) initiated by China, some South Asian countries like Pakistan, Sri Lanka and Bangladesh have provided positive support for the initiave of China, namely the Asian Infrastructure Investment Bank (AIIB) (Yu, 2010). The MSR initiative is a step in expanding China's presence in the Indian Ocean region, with the development of ports and infrastructure development. Thus, not only do South Asian countries benefit from this relationship and closeness to China, but China also considers that these countries are important equal partners for strategic reasons.

India's interests in South Asia, despite of its conflicts with Pakistan, Sri Lanka and Bangladesh, encourage India itself to search for natural resources and to secure energy supply routes along the Indian Ocean region. Hence, South Asian countries are considered not included in the ownership of large natural resource deposits when compared to African countries where India is involved in resource extraction. On the other hand, the benefits are from its strategic location closeness with Pakistan, Sri Lanka and Bangladesh. That has awakened India's desire to connect with these countries. Because the port is the point of the route to be traversed in connection with the interests of transporting oil, natural resources and manufactured goods which are very important for India, these countries are also important for India for economic, political and diplomatic reasons.

The Nehru Memorial Museum and Library (NMML) on May 8, 2019, held a panel discussion with the theme Political Contours of the Indo-Pacific Region attended by around 50 participants from academia and diplomatic representatives in New Delhi. Some of the deliveries at the discussion included tha Indian version of the Indo-Pacific (IP) framework will include some main player countries at IP, SAGAR India's policies regarding IP and Western region IP and their political and security interests. (https://www.youtube.com/watch?v=618nPIP9PfA). The unique interaction on IP cooperation between India and Japan has a relatively similar understanding to develop connectivity in the West IP region that connects Asian regions (including ASEAN) with Africa and Europe to offset the strong growth of China's BRI threats. The existence of TPP (Trans Pacific Partnership, which was initiated in the era of President Obama) is very important for Japan, although TPP has been replaced by President Trump to become RCEP (Regional Comprehensive Economic Partnership) which is considered to have no significant progress to support Japanese interests in politics, economy and security due to the strengthening of the China's BRI in the Western Pacific region. This is related to the rivalry between China and the US to fight for influence in the Asia-Pacific region by emphasizing the freedom to navigate the sea and air. The US is considered to have challenged by the emerging existence of China in maritime domain by strengthening the capabilities of Japan, South Korea and Taiwan's nuclear missiles. These actions were answered by China by developing the capabilities of their missiles and nuclear weapons, which could potentially become open conflicts in the South China Sea (LCS).

In terms of military spending, the results of a study conducted by the Stockholm International Peace Research Institute (SIPRI) showed that five major players, namely the United States, China, Saudi Arabia, India and France continued to increase by USD 1,822 million USD in 2018, an increase of $2.6 \%$ from 2017. The military spending of the five countries constitutes $60 \%$ of the world's military spending which is dominated by the US and China. In particular, India experienced an increase in military spending of 3.1\% (USD $66.5 \mathrm{M}$ ), while Pakistan remained the same as in 2017 at an increase of $11 \%$ (USD $11.4 \mathrm{M}$ ). India's role is expected to be more proactive in developing partnerships with countries in the Indo-Pacific region in the field of trade and technology cooperation through the development of the power of maritime security to develop infrastructure to support regional connectivity, both sea and air.

During the panel discussion at NMML, it was assessed that there were differences in understanding of the basic concepts of Indo-Pacific (IP) initiated by Quad Indo-Pacific (US, Japan, Australia and India) to balance China's BRI which had not been completed together. The US 
illustrates that the IP area covers the waters of the western part of India to the western waters of the US (White House, National Security Strategy of the United States, December 2017). Meanwhile, Australia describes the IP area starting from the east coast of the Indian Ocean and the Pacific Ocean is connected through ASEAN waters including India, North Asia and the US (White Paper on Foreign Policy, 2017). Japan assesses the concept of IP must be seen as a whole as an area that covers two continents of Asia and Africa and two oceans of the Pacific and the Indian (Mukerji, 2019). India considers that the concept of IP is a region that is free, open, and inclusive region and should not be controlled by certain countries, giving freedom of navigation in the sea and air and puts ASEAN centrality as a point of unification or convergence of the Pacific and Indian Ocean regions. Connectivity development must be mutually developed and be beneficial among regional countries through strengthening international cooperation. This was stated by India's Prime Minister, Narendra Modi regarding his policy on Indo-Pacific which was delivered in Shangri-La Dialogue in Singapore, 1 June 2018 based on Indian Ocean Policy or SAGAR (Security and Growth for All in the Region, March 2015) (https://usiofindia.org/publication/usi-journal/prospects-for-thequad-in-the-indo-pacific/).

Through the understanding of SAGAR Policy, the Government of India is currently considered to be trying to strengthen its existence as a security net in the IP region in order to encourage the development of marine economies that can improve shared prosperity to face the major players in the region. At present, the US is considered to have an interest in developing its naval power in the waters of the western part of India to offset the progress of China's BRI growth. While Japan is considered to have a tendency to converge the IP area with African waters through strengthening its economy supported by the development of navy forces, China is currently considered to be focusing its main focus on LCS regarding the dynamics of the Spratly Islands dispute with countries in the region. China also shows increased attention to waters in the Indian Ocean, especially on the east coast of Africa and the Gulf region through the development of marine and land infrastructure supported by modernization of its armed forces. For an example of ASEAN's centrality outlook, Indonesia is considered to be focused on building economic strength by promoting the centrality of an inclusive ASEAN. France is considered unilaterally to have declared itself as a force in the Indian Ocean by developing its navy's capabilities in various islands to control IP. The last major power is Russia, which is currently also considered to have an interest in the rise of the IP region with a focus on developing its navy strength to deal with the continuation of territorial disputes with Japan in the Pacific (https://currentaffairs.gktoday.in/tags/sagar).

The current Indian Government policy has a tendency to focus attention on the western IP region of the west coast of India. This is due to economic, technological and security considerations. Economically, India is considered aware that there are 8 million citizens who work in the Gulf region and have sent money to India for USD $10 \mathrm{M}$ annually. In addition, the development of industry and the domestic economy of India is highly dependent on the continued support of the abundant oil resources in the Gulf region. In the field of digital technology, India has underwater fiber optic cable infrastructure since 2000. In 2011, this infrastructure has connected India's digital economy with the world especially with the EU which has resulted in the ease of conducting various transactions and virtual trading activities online (Assocham, 2016). Meanwhile, in terms of security, there are two main focuses of India, namely the Choke Point trade that crosses the Sea Line of Communication (SLOC) which is prone to piracy attacks, especially in the waters of East Africa (Somalia) and the Strait of Hormuz. In addition to the threat of sea piracy, India is now also considered increasingly focused on observing the Gulf region after the Easter Bomb attack in Sri Lanka to counter terrorism against the potential ISIS threat to India which is predominantly from the Middle East region (Khalid, 2012). In the monthly report of the Ministry of Finance of India for March 2019, it was confirmed that the Indian economy in the 2018-19 fiscal year experienced a slowdown. This is due to a decline in growth in private consumption, an increase in fixed investment, and a reduction in exports because at the same time the Government of India is holding the 2019 Lok Sabha Election which will end on May 23, 2019.

At present the challenge in increasing India's domestic economic growth lies in efforts to reverse the slowdown in growth in the agricultural sector and to maintain growth in the domestic industry sector. Meanwhile, from the external side, it is carried out with strict management of a 
balance sheet deficit because the ratio of gross domestic product (GDP) will experience a decline in Q4 of 2018-19 fiscal year. GDP growth for the last quarter of $2018-19$ is estimated at $6.5 \%$ of the $7 \%$ GDP target and continues to decline which is estimated at $3.4 \%$. The current account deficit for GDP is expected to increase in the third and fourth quarters of fiscal year 2018-19 because the decline in imports has increased the goods trade deficit. In order to overcome these problems, the Indian government must issue a more flexible monetary policy in providing stimulus for national economic growth through cutting interest rates and in strengthening national banking liquidity (https://www.ibef.org/industry/financial-services-india.aspx).

The weakening of the production sector in India, according to CMIE has caused an increase in the unemployment rate per April 25,2019 by $7.5 \%$. The average unemployment rate in the first three weeks of April 2019 was $8.1 \%$ with the detail, in the first week, it was $7.9 \%$, in the second week it was $8.1 \%$ and in the third week it was $8.4 \%$, respectively. Therefore, the overall unemployment rate on April 25 was $7.5 \%$, much higher than March 2019 at $6.7 \%$. In other terms, the labor force participation rate shows a greater proportion of the population of job-seeking adults which has reached $44.3 \%$ on April 14, 2019, compared to $42.3 \%$ in the first three weeks of March 2019 (https://www.cmie.com/kommon/bin/sr.php?kall=warticle\&dt=2019-01-08\%2009:28:37\&msec=666).

By looking at these India's domestic problems and its outlook for maritime policy, Southeast Asian countries will be likely to affected by expansionist Indian policies from various fields, resulting in the importance of reorientation of strategies so as to bridge Indonesia's national interests with South Asian region without seeming ambitious in the context of international relations.

\section{Conclusion}

India in the 21st century has given rise to a new perception related to the dominance of the international order as the new rising global power. India places its position as a major power seen from the magnitude of India's ambition to become a super power country. This tendency can be analyzed through India's internal doctrine, namely look east policy starting at Narasimha Rao, accompanied by formulations that extend its scope to throughout Asia to make India as a major power and great leader for developing countries in the Third World. With the growing economy and domestic energy needs, India is increasingly developing its presence in various regions around the Indian Ocean, especially to secure its interests and energy supply lines. Here, the Southeast Asian region will become a major region in the struggle for influence, where most of the global trade in traffic and oil crosses this region. Some Southeast Asian countries have alliances with Western countries, while some others in the last few cases defending Chinese interests. The increasing presence of India in this region can be a new challenge, as well as an opportunity, for Southeast Asian countries to be able to be a non-alligment buffer zone from various world powers, and be able to attract foreign investment and increase the capacity of international trade for ASEAN members.

Moreover, although there was a slowdown in the growth of the Indian economy, there were still other commodities from Southeast Asian countries with high demand at competitive prices which could enter the Indian market. For instance, Indonesian paper products have a great demand by India, where paper prices from Indonesia are much cheaper compared to China. Thus, it is very likely to be able to enter the Indian market, including several other superior commodities. The increase in Sino-Indian tensions can be an opportunity to strengthen Indonesia's dominant influence in ASEAN as the Sea Line of Communication (SLoC) region in connecting the waters of the Pacific Ocean with the Indian Ocean. The very strategic existence of Indonesian waters, as well as geostrategic positions of Southeast Asia, will encourage a stronger tendency for influence between the Indo-Pacific regime versus China's BRI regime. This condition must continue to be developed optimally to encourage the development of Indonesia's domestic economy, especially along the Indonesian Archipelago Sea Flow Line (SLoC 1 to SLoC 3) based on UNCLOS 1982, which will be utilized by both regimes to cross their respective fleets. 


\section{Reference}

Aneez, S., \& Srilal, R. (2014). Chinese submarine docks in Sri Lanka despite Indian concerns. Reuters, November 2, 2014. Retrieved from http://in.reuters.com/article/2014/11/02/sri-lanka-chinasubmarineidINKBNOIMOLU20141102

ASSOCHAM. (2016, November). Digital IndiaUnlocking the Trillion Dollar Opportunity. India: Delloite India

Berlin, D. L. (2006). India in the Indian ocean. Naval War College Review, 59(2), 58-89.

Brewster, D. (2010). An Indian sphere of influence in the Indian Ocean?. Security Challenges, 6(3), 1-20.

Chaturvedy, R. R. (2017). The Indian Ocean Policy of the Modi Government. In Singh, S. (Ed.), Modi And The World: $(R e)$ Constructing Indian Foreign Policy (pp. 163-184). Singapore: World Scientific

Cordner, L. (2010). Rethinking maritime security in the Indian Ocean Region. Journal of the Indian Ocean Region, 6(1), 67-85.

Hopewell, K. (2015). Different paths to power: The rise of Brazil, India and China at the World Trade Organization. Review of international political economy, 22(2), 311-338.

https://currentaffairs.gktoday.in/tags/sagar

https://usiofindia.org/publication/usi-journal/prospects-for-the-quad-in-the-indo- pacific/

https://www.ceicdata.com/id/indicator/india/total-exports

https://www.cmie.com/kommon/bin/sr.php?kall=warticle\&dt=2019-01-08\%2009:28:37\&msec=666

https://www.ibef.org/industry/financial-services-india.aspx

https://www.youtube.com/watch?v=618nPIP9PfA

John J. Mearsheimer, The Tragedy of Great Power Politics, (New York: W. W. Norton, 2001), 131

Khalid, N. (2012). Sea Lines Under Strain: The Way Forward in Managing Sea Lines of Communication. IUP Journal of International Relations, 6(2).

Ladwig III, W. C. (2009). Delhi's Pacific ambition: Naval power,"Look East," and India's emerging influence in the Asia-Pacific. Asian Security, 5(2), 87-113.

Mahan, A. T. (2013). The influence of sea power upon history, 1660-1783. Read Books Ltd.

Mukerji, S.A.K. (2019). Prospects for the Quad in the Indo-Pacific. Journal of the United Service Institution of India 149(615). Retrieved Aug. 23, 2019, from https://usiofindia.org/publication/usi-journal/prospects-forthe-quad-in-the-indo-pacific/

Pant, H. V. (2009). India in the Indian Ocean: growing mismatch between ambitions and capabilities. Pacific Affairs, 82(2), 279-297.

Sachs, J. D. (2004). Welcome To The Asian Century By 2050, China and maybe India will overtake the US economy in size. Fortune Magazine.

Sakhuja, V. (2011). Asian maritime power in the 21st century: Strategic transactions: China, India and Southeast Asia. Institute of Southeast Asian Studies.

Yu, J. (2010). Pakistan welcomes AlIB announcement. Global Times, 25 October 2010. Retrieved from http:// www .globaltimes.cn/content/888238.shtml 